\title{
TRANSIENT OBSTRUCTIVE HYDROCEPHALUS IN PATIENTS WITH INTRACEREBRAL HEMORRHAGE: REPORT OF TWO CASES
}

\author{
Ilija Jergović ${ }^{1}$, Hrvoje Budinčević ${ }^{1,2}$, Miljenka Planjar-Prvan ${ }^{1}$ and Ivan Bielen ${ }^{1,2}$ \\ ${ }^{1}$ Stroke and Intensive Care Unit, Clinical Department of Neurology, Sveti Duh University Hospital; \\ ${ }^{2}$ School of Medicine, Josip Juraj Strossmayer University of Osijek, Osijek, Croatia

\begin{abstract}
SUMMARY - Obstructive hydrocephalus is a relatively common complication of intraventricular hemorrhage resulting in high morbidity and mortality. We report two cases of transient obstructive hydrocephalus caused by obstruction of mesencephalic duct in patients that presented with altered consciousness which resolved spontaneously in a few hours. In very rare cases, obstructive hydrocephalus due to intraventricular hemorrhage may be transient and does not need neurosurgical or invasive procedures for lowering raised intracranial pressure, which otherwise are currently preferred treatment options.
\end{abstract}

Key words: Hydrocephalus - complications; Acute disease; Cerebral ventricles - pathology; Cerebral hemorrbage - complications; Case reports

\section{Introduction}

Obstructive hydrocephalus is a relatively common complication of intraventricular hemorrhage (IVH) resulting in high morbidity and mortality. The classical hypothesis of cerebrospinal fluid (CSF) low dynamics is seemingly based on misinterpretation and cannot provide answers to many clinical questions ${ }^{2}$. Transient obstructive hydrocephalus has been described very rarely and was caused by mesencephalic duct obstruction that resolved spontaneously after $\mathrm{IVH}^{3,4}$.

In this paper, we report two cases of transient obstructive hydrocephalus caused by mesencephalic duct obstruction, which resolved spontaneously without neurosurgical intervention.

\section{Case 1}

The first patient was a 65-year-old man who complained of mild occipital headache with nausea 4 days

Correspondence to: Hrvoje Budinčevič, $M D, P h D$, Stroke and Intensive Care Unit, Clinical Department of Neurology, Sveti Duh University Hospital, Sveti Duh 64, HR-10000 Zagreb, Croatia E-mail: hbudincevic@gmail.com

Received October 9, 2014, accepted February 19, 2016 prior to admission to the hospital. On the day of admission, he became soporuos, without motor deficit or cranial nerve palsy. At presentation, his arterial blood pressure was 130/80 mm Hg. His physical examination and previous medical history was unremarkable, with confirmation of light alcohol consumption (a few drinks per week). He had elevated levels of gammaglutamyltransferase (GGT; 96 IU/L), total cholesterol $(5.98 \mathrm{mmol} / \mathrm{L})$ and low-density lipoprotein (LDL) cholesterol (4.29 mmol/L). Computed tomography (CT) scan revealed intracerebral hemorrhage (ICH) originating from the right occipital lobe with IVH in the right lateral and third brain ventricles (Fig. 1a), along with obstruction of the mesencephalic duct and development of obstructive hydrocephalus (Fig. 1b). The patient was immediately treated with antiedematous therapy (20\% mannitol 4x125 mL for 3 days) and a few hours after admission to the Intensive Care Unit (ICU), the patient became fully awake, being only slightly disoriented in space and time. During hospitalization, repeated brain CT and brain magnetic resonance imaging (MRI) scans did not show signs of hydrocephalus (Fig. 1c), with gradual resorption of IVH 


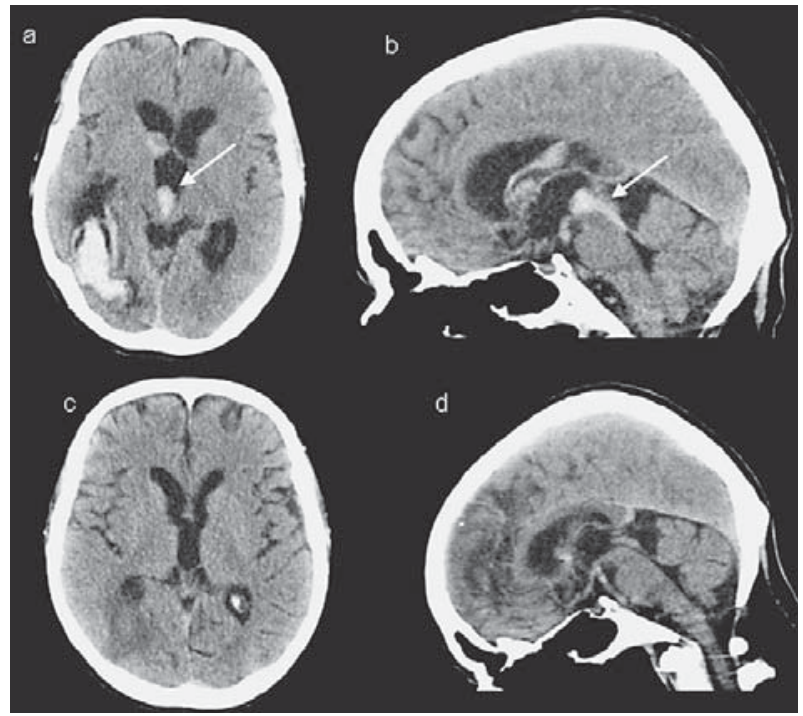

Fig. 1. Initial brain CT on day 1 shows intraventricular hemorrbage in the right lateral and third brain ventricle (arrows) with obstructive hydrocephalus (a); initial brain $C T$ on day 1 shows intraventricular hemorrbage in the mesencephalic duct (arrow) with obstructive bydrocephalus (b); follow up brain CT on day 3 shows resolved intraventricular hemorrhage without signs of acute hydrocephalus (c); follow up brain CT on day 17 shows resolved intraventricular hemorrhage and resorption of intraventricular hemorrhage (d).

and ICH (Fig. 1d). MRI angiography did not show any arteriovenous malformations (AVM) or aneurysms. The patient was discharged on day 18 after admission, with only subtle cognitive decline (Montreal cognitive assessment (MoCA) test 24 points).

\section{Case 2}

The second patient was a 66-year-old woman who was admitted to the hospital, disoriented, agitated, complaining of headache and vomiting. All of the symptoms developed on the day of admission. Neurological examination showed no motor deficit or cranial nerve palsy and her physical examination was unremarkable. At presentation, her arterial blood pressure was 140/70 mm Hg. Her previous medical history included arterial hypertension, hyperlipidemia, bronchial asthma, cholecystectomy and bilateral gonarthrosis with implanted total endoprosthesis of the left knee. Initial CT scan showed IVH in the mesencephalic duct (Fig. 2a and 2b) and in the occipital horn of the

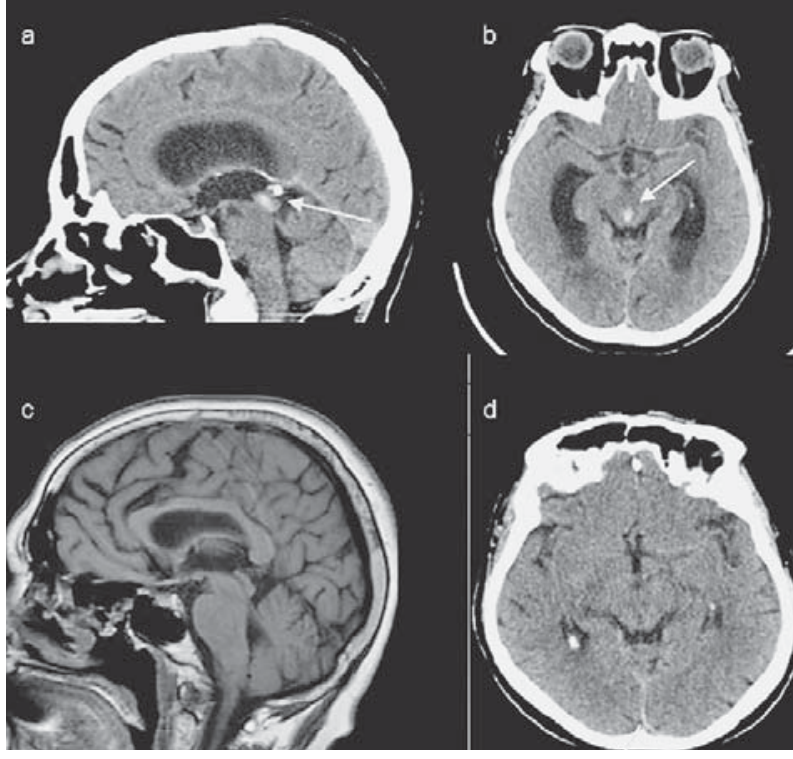

Fig. 2. Initial brain CT on day 1 shows intraventricular hemorrhage in the mesencephalic duct (arrow) (a); initial brain CT on day 1 shows intraventricular hemorrhage in the mesencephalic duct (arrow) (b); brain MRI on day 3 shows resolved intraventricular hemorrhage without signs of acute bydrocephalus (c); follow up brain CT on day 9 shows resolved intraventricular hemorrhage without signs of acute hydrocephalus (d).

right lateral ventricle. The patient was treated with antiedematous therapy (20\% mannitol 4x125 mL for 3 days) and a few hours after admission to the ICU, she became almost fully oriented. She was without neurological deficit a couple of days later. Follow up brain MRI (Fig. 2c) and CT scans showed gradual resorption of previously described IVH (Fig. 2d). MRI angiography showed no AVM or brain aneurysms.

The patient was discharged on day 10 after admission, without neurological deficit.

\section{Discussion}

Both of our patients presented with altered consciousness due to IVH which caused acute obstructive hydrocephalus by obstructing the mesencephalic duct. According to the classical hypothesis of cerebrospinal fluid (CSF) flow dynamics, CSF is produced within the ventricular system and it circulates toward the subarachnoid space where it is absorbed and a blockage between ventricular and subarachnoid spaces would 
cause an increase of intraventricular pressure and dilatation of brain ventricles 5 . However, recent findings by Klarica et al. suggest that a blockage between ventricular and subarachnoid spaces alone does not result in a significant increase of intraventricular pressure ${ }^{6}$. A simultaneous blockage of CSF flow and influx of a new volume of CSF (as in IVH) can lead to an increase of CSF pressure and development of the transmantle pressure gradient causing an acute hydrocephalus, which was the case in our two patients ${ }^{6}$.

The new hypothesis of CSF flow dynamics proposed by Oreskovic and Klarica suggests that interstitial fluid (ISF) and CSF bulk (water) form a functional unity and are regulated by changes in osmotic and hydrostatic pressure in CNS microvessels ${ }^{7}$. According to this hypothesis, formation and absorption of CSF mainly take place at the cerebral capillaries and the total CSF volume within the CSF system depends on the ISF-CSF functional unit that is affected by physiological and pathological processes which cause differences in fluid osmolarity between CNS compartments ${ }^{7}$.

In cases of acute obstructive hydrocephalus following IVH, therapeutic options are external ventricular drainage, concomitant use of intraventricular fibrinolytics such as recombinant tissue plasminogen activator or urokinase, as well as endoscopic retrieval of intraventricular blood ${ }^{8}$. Osmotic agents such as mannitol can be effective in the short-term management of raised intracranial pressure ${ }^{9}$. We considered neurosurgical treatment with ventricular drainage but because of rapid resolution of the symptoms such treatment was unnecessary.

Previous literature on acute obstructive hydrocephalus has suggested that CSF with its fibrinolytic activity increases intraventricular pressure and causes a hyperdynamic CSF flow, as well as proximal aqueduct dilatation, which can break down the clot and resolve hydrocephalus $^{3}$. We believe that in our two cases, the pressure gradient was the main reason of clot resolution, thus relieving hydrocephalus, with consequential osmotic changes in the ISF-CSF functional unit, allowing blood re-absorption from the ventricular system.

In conclusion, in very rare cases, obstructive hydrocephalus due to IVH may be transient and does not need neurosurgical or invasive procedures for lowering elevated intracranial pressure, which otherwise still are the preferred options in the treatment of these patients $^{8}$

\section{References}

1. Strahle J, Garton HJ, Maher CO, Muraszko KM, Keep RF, Xi G. Mechanisms of hydrocephalus after neonatal and adult intraventricular hemorrhage. Transl Stroke Res. 2012;3:25-38. doi: 10.1007/s12975-012-0182-9

2. Chikly B, Quaghebeur J. Reassessing cerebrospinal fluid (CSF) hydrodynamics: a literature review presenting a novel hypothesis for CSF physiology. J Bodyw Mov Ther. 2013;17:344-54. doi: 10.1016/j.jbmt.2013.02.002

3. Lusis EA, Vellimana AK, Ray WZ, Chicoine MR, Jost SC. Transient obstructive hydrocephalus due to intraventricular hemorrhage: a case report and review of literature. J Clin Neurol. 2013;9:192-5. doi: 10.3988/jcn.2013.9.3.192

4. Nomura S, Orita T, Tsurutani T, Kajiwara K, Izumihara A. Transient hydrocephalus due to movement of a clot plugging the aqueduct. Comput Med Imaging Graph. 1997;21:351-3.

5. Brodbelt A, Stoodley M. CSF pathways: a review. Br J Neurosurg. 2007;21:510-20. doi: 10.1080/02688690701447420

6. Klarica M, Oreskovic D, Bozic B, Vukic M, Butkovic V, Bulat M. New experimental model of acute aqueductal blockage in cats: effects on cerebrospinal fluid pressure and the size of brain ventricles. Neuroscience. 2009;158:1397-405. doi: 10.1016/j. neuroscience.2008.11.041

7. Oreskovic D, Klarica M. Development of hydrocephalus and classical hypothesis of cerebrospinal fluid hydrodynamics: facts and illusions. Prog Neurobiol. 2011;94:238-58. doi: 10.1016/j. pneurobio.2011.05.005

8. Gaberel T, Magheru C, Emery E. Management of non-traumatic intraventricular hemorrhage. Neurosurg Rev. 2012;35: 485-94; discussion 494-5. doi: 10.1007/s10143-012-0399-9

9. Brouwers HB, Goldstein JN. Therapeutic strategies in acute intracerebral hemorrhage. Neurotherapeutics. 2012;9:87-98. doi: 10.1007/s13311-011-0091-8 


\title{
Sažetak \\ PROLAZNI OPSTRUKTIVNI HIDROCEFALUS U BOLESNIKA S INTRACEREBRALNIM KRVARENJEM: PRIKAZ DVAJU SLUČAJEVA
}

\author{
I. Jergovic, H. Budinčević, M. Planjar-Prvan i I. Bielen
}

Opstruktivni hidrocefalus je relativno česta komplikacija intraventrikulskog krvarenja, što doprinosi visokom pobolu i smrtnosti. Cilj ovoga rada je prikazati dvoje bolesnika s prolaznim opsktruktivnim hidrocefalusom koji je uzrokovan opstrukcijom u području mezencefaličkog duktusa. Oboje bolesnika su se prezentirali prolaznim poremećajem stanja svijesti u trajanju od nekoliko sati. U rijetkim slučajevima opstruktivni hidrocefalus uzrokovan intraventrikulskim krvarenjem može biti prolazne naravi i tada nema potrebe za neurokirurškim ili drugim invazivnim postupcima radi sniženja povišenog intrakranijskog tlaka.

Ključne riječi: Hidrocefalus - komplikacije; Akutna bolest; Moždane komore - patologija; Cerebralno krvarenje - komplikacije; Prikazi slučaja 